Review

\title{
Epigenetic Disregulation in Oral Cancer
}

\section{Massimo Mascolo ${ }^{1}$, Maria Siano ${ }^{1}$, Gennaro Ilardi ${ }^{1}$, Daniela Russo ${ }^{1}$, Francesco Merolla ${ }^{1}$, Gaetano De Rosa ${ }^{1,2}$ and Stefania Staibano ${ }^{1, *}$}

1 Department of Biomorphological and Functional Sciences, Pathology Section, University of Naples “Federico II”, Naples 80131, Italy; E-Mails: mmascol@gmail.com (M.M.); dysian@tin.it (M.S.); gennaro.ilardi@unina.it (G.I.); danielarusso83@yahoo.it (D.R.); francesco.merolla@unina.it (F.M.); gaderosa@unina.it (G.D.R.)

2 Centro di Riferimento Oncologico di Basilicata (C.R.O.B.) Oncology Research Center of Basilicata, Rionero in Vulture, Potenza 85028, Italy

* Author to whom correspondence should be addressed; E-Mail: staibano@unina.it; Tel.: +39-81-7462368; Fax: +39-81-7463414.

Received: 6 December 2011; in revised form: 9 February 2012 / Accepted: 13 February 2012 / Published: 21 February 2012

\begin{abstract}
Squamous cell carcinoma of the oral region (OSCC) is one of the most common and highly aggressive malignancies worldwide, despite the fact that significant results have been achieved during the last decades in its detection, prevention and treatment. Although many efforts have been made to define the molecular signatures that identify the clinical outcome of oral cancers, OSCC still lacks reliable prognostic molecular markers. Scientific evidence indicates that transition from normal epithelium to pre-malignancy, and finally to oral carcinoma, depends on the accumulation of genetic and epigenetic alterations in a multistep process. Unlike genetic alterations, epigenetic changes are heritable and potentially reversible. The most common examples of such changes are DNA methylation, histone modification, and small non-coding RNAs. Although several epigenetic changes have been currently linked to OSCC initiation and progression, they have been only partially characterized. Over the last decade, it has been demonstrated that especially aberrant DNA methylation plays a critical role in oral cancer. The major goal of the present paper is to review the recent literature about the epigenetic modifications contribution in early and later phases of OSCC malignant transformation; in particular we point out the current evidence of epigenetic marks as novel markers for early diagnosis and prognosis as well as potential therapeutic targets in oral cancer.
\end{abstract}


Keywords: epigenetics; oral cancer; tumor progression; prognosis; molecular therapy

\section{Introduction}

Head and neck cancers constitute the sixth most common malignant tumors worldwide, affecting approximately 650,000 people and causing almost 350,000 cancer deaths per year [1,2]. These malignancies encompass tumors arising from the epithelium of the nasal and oral cavity, paranasal sinus, pharynx and larynx. Oral cancer is the most frequent cancer of the head and neck district, with squamous cell carcinoma being by far the commonest single entity, accounting alone for about $90 \%$ of all malignancies of the oral cavity [3]. Due to its related high mortality and low cure rate, oral squamous cell carcinoma (OSCC) represents a major public health problem, with a great individual and socioeconomic impact. In fact, despite of the many advancements made in the field of oral cancer prevention and multimodality treatments, the five-year survival rate for OSCC remains at a disappointingly stable level, almost unchanged over the past 20 years [4,5]. The poor prognosis of OSCC is mainly due to a low response rate to current therapeutic strategies, particularly for tumors diagnosed in advanced stage. This specific subset of patients is characterized by a high occurrence of invasion to surrounding tissues, lymph node and distant metastasis and by a peculiarly high risk of second malignancy during the patient's lifetime.

Oral carcinogenesis is a multistep process modulated by endogenous and environmental factors. Among these latter, a major role is played by tobacco and alcohol regular intake [6], as well as by Human Papillomavirus (HPV) persistent infection [7-11]. These predisposing factors may lead to a wide range of genetic and epigenetic events that promote genomic instability and tumor development and progression. The genetic alterations involved in the development and progression of oral premalignancy and OSCC, are caused by irreversible changes in DNA sequence including gene deletions, amplifications and mutations leading both to oncogenes activation or tumor suppressor genes inactivation $[12,13]$.

Epigenetics is another major player in multistep carcinogenesis of oral cancers. Here we discuss the current literature in the field of the epigenetics of oral cancer, placing a great deal of emphasis on DNA methylation, histone modification and post-transcriptional gene down-regulation by microRNAs. The emerging but still debated role of high-risk HPV persistent infections in determining a different subset of OSCC will also be discussed, reviewing some of recent publications about this topic and pointing out the relationship between HPV infection and cancer prone epigenetic modifications. We finally aim to highlight the important translational implications of the epigenetic regulation as new diagnostic, prognostic and predictive markers in oral cancer, an actually growing field of research due to the poor reliability of conventional markers in OSCC diagnosis, treatment and follow-up [12].

\section{Epigenetics}

The epigenetic changes refer to any heritable modifications in gene expression without alterations of the DNA sequence; they occur more frequently than gene mutations and may persist for the entire cell life and even for multiple generations [14]. The transcription of each gene may change from 
high-level expression to complete silencing, depending on the influence of the "epimutations" which interfere with the action of activators and suppressors on specific promoters in the chromatin context [15]. With minor exceptions ( $\mathrm{T}$ - and B-cells of the immune system), all differentiation processes are triggered and maintained through epigenetic mechanisms. Epigenetic inheritance includes DNA methylation, histone modifications and RNA-mediated silencing. Disruption of any of these three distinct and mutually reinforcing epigenetic mechanisms leads to inappropriate gene expression, resulting in cancer development and other "epigenetic diseases" [16-19] (Table 1).

Table 1. The most common epigenetic alterations.

\begin{tabular}{|c|c|c|}
\hline Epigenetic change & Putative mechanism & Biological consequence \\
\hline \multirow[t]{2}{*}{ DNA hypomethylation } & Activation of cellular oncogenes & Increased proliferation, growth advantage \\
\hline & Activation of transposable element & Genomic instability, transcriptional noise \\
\hline DNA hypermethylation & $\begin{array}{l}\text { De novo hypermethylation of } \mathrm{CpG} \text { islands } \\
\text { within gene promoters leading to silencing of } \\
\text { tumor suppressors and cancer-associated genes }\end{array}$ & $\begin{array}{l}\text { Genomic and chromosomal instability, } \\
\text { increased proliferation, growth advantage }\end{array}$ \\
\hline Loss of imprinting (LOI) & $\begin{array}{l}\text { Reactivation of silent alleles, biallelic expression } \\
\text { of imprinted genes }\end{array}$ & Expansion of precursor cell population \\
\hline $\begin{array}{l}\text { Relaxation of X- } \\
\text { chromosome inactivation }\end{array}$ & $\begin{array}{l}\text { Mechanisms is unknown but it appears to be } \\
\text { age-related }\end{array}$ & Altered gene dosage, growth advantage \\
\hline \multirow[t]{2}{*}{ Histone acetylation } & Gain-of-function & Activation of tumor promoting genes \\
\hline & Loss-of-function & Defects in DNA repair and checkpoints \\
\hline Histone deacetylation & Silencing of tumor suppressor genes & Genomic instability, increased proliferation \\
\hline Histone methylation & $\begin{array}{l}\text { Loss of heritable patterns of gene expression } \\
\text { ("cellular memory") }\end{array}$ & Genomic instability, growth advantage \\
\hline $\begin{array}{l}\text { MicroRNAs (miRNAs) } \\
\text { amplification in cancer }\end{array}$ & Function as oncogenes & Neoplastic transformation \\
\hline $\begin{array}{l}\text { MicroRNAs (miRNAs) } \\
\text { deletion in cancer }\end{array}$ & Function as tumor suppressors. & Neoplastic transformation \\
\hline
\end{tabular}

\section{DNA Methylation}

DNA methylation is the most common and the best-studied epigenetic modification [20]. It is mediated by different DNA methyltransferases (DNMT) [21] and usually involves lysine and arginine residues on histone tails. The methylation of DNA refers to the covalent addition of a methyl group to the 5-carbon (C5) position of cytosine bases that are located $5^{\prime}$ to a guanosine base in a $\mathrm{CpG}$ dinucleotide. $\mathrm{CpG}$ dinucleotides, scattered throughout the genome, are usually found clustered in 0.5-4 kb regions, named $\mathrm{CpG}$ islands, the major part of which localized at the promoter of tumor suppressor genes [22]. $\mathrm{CpG}$ islands of growth-regulatory genes promoter regions are often found hypermethylated in tumors, this event causing the transcriptional "silencing" of tumor suppressor genes [23,24], contributing to cancer progression; on the contrary, it has also been described the derepression of proto-oncogenes transcription by hypo/demethylation, this leading to increased mutation rates and to chromosome instability, which constitutes an early hallmark of tumor cells [25-27]. Moreover, the loss of function of tumor-suppressor genes, which often occurs in tumors, has been ascribed more frequently to epigenetic silencing through methylation than to genetic 
defects [20,28], supporting the hypothesis that epigenetic alterations have a significant role in every step of carcinogenesis. The genes most frequently hypermethylated and silenced in cancer cells reside in chromosome regions commonly showing loss of heterozygosity. The LOH of hypermethylated genes may provide a selective growth advantage to tumor cells, and is often involved in metastatic ability and in tumor neo-angiogenesis [29].

\section{DNA Methylation in Oral Carcinogenesis}

Although a clear correlation between the epigenetic-driven deregulation of gene expression and the oral cancer progression is at present not fully demonstrated, hypermethylation and consequent silencing of several tumor suppressor genes, out of a group of more than 40 genes, has been identified in OSCC [20] (Table 2); the genes found hypermethylated in OSCC cover a wide range of cellular processes, including cell cycle control (p16, p15), apoptosis (p14, DAPK, p73 and RASSF1A), Wnt signalling (APC, WIF1, RUNX3), cell-cell adhesion (E-cadherin), and DNA-repair (MGMT and hMLH1) [30-33].

Table 2. The most common genes silenced from promoter methylation.

\begin{tabular}{|c|c|c|c|c|}
\hline Gene & Locus & Function & Alterations & Ref \\
\hline$A B O$ & $9 \mathrm{q} 34$ & Blood group antigen & Hypermethilation & 34 \\
\hline APC & $5 q 21$ & Signal transduction & Hypermethilation & 33,35 \\
\hline ATM & $11 q 22-q 23$ & Tumor suppressor & Hypermethilation & $4,30,36,37$ \\
\hline$C / E B P a$ & $19 q 13$ & Tumor suppressor & Hypermethilation & 38 \\
\hline CDKN2A & $9 \mathrm{p} 21$ & Cell cycle & LOH, hypermethilation & 4,39 \\
\hline CRABP2 & $1 \mathrm{q} 21$ & $\begin{array}{l}\text { Nuclear transcriptional } \\
\text { regulator }\end{array}$ & Hypermethilation & 40 \\
\hline DAPK & $9 q$ & Apoptosis & Hypermethilation & $4,30,32,34,35,37$ \\
\hline$D C C$ & $18 \mathrm{q} 21$ & Tumor suppressor & Hypermethilation & $4,30,34,37$ \\
\hline DKK3 & $11 \mathrm{p}$ & Transcriptional regulator & Hypermethilation & 12 \\
\hline E-cadherin & $16 \mathrm{q} 22$ & Signal transduction & Hypermethilation & $4,32,41,42,34,36$ \\
\hline EDNRB & $13 \mathrm{q} 22$ & Signal transduction & Hypermethilation & 39 \\
\hline GSTP1 & $11 \mathrm{q} 13$ & Detoxification of carcinogens & Hypermethilation & 30,43 \\
\hline Н3К4 & $1 \mathrm{q} 21.2$ & Histone & Hypermethilation & 44 \\
\hline HIN1 & $12 \mathrm{p} 13$ & Tumor suppressor & Hypermethilation & 45 \\
\hline Hmlh1 & $3 \mathrm{p} 21$ & DNA repair & Hypermethilation & $30,32,34-36$ \\
\hline LHX6 & $9 \mathrm{q} 33$ & Transcriptional regulator & Hypermethilation & 38 \\
\hline MGMT & $10 \mathrm{q} 26$ & DNA repair & Hypermethilation & $4,30,32,41,35,37$ \\
\hline MINT family & 1 & 1 & Hypermethilation & 30 \\
\hline $\operatorname{miR137}$ & $1 \mathrm{p} 21.3$ & Tumor suppressor & Hypermethilation & 46 \\
\hline miR193a & $17 \mathrm{q} 11.2$ & Tumor suppressor & Hypermethilation & 46 \\
\hline MX1 & $21 \mathrm{q} 22$ & 1 & Hypermethilation & 40 \\
\hline p14 & $9 \mathrm{p} 21$ & Apoptosis & LOH, hypermethilation & 30,34 \\
\hline p15 & $9 \mathrm{p} 21$ & Cell cycle & $\begin{array}{l}\text { LOH, deletion, mutation, } \\
\text { hypermethilation }\end{array}$ & 4,37 \\
\hline p16 & $9 \mathrm{p} 21$ & Cell cycle & $\begin{array}{l}\mathrm{LOH}, \text { mutation, deletion, } \\
\text { hypermethilation }\end{array}$ & $30,32,35-38$ \\
\hline
\end{tabular}


Table 2. Cont.

\begin{tabular}{|c|c|c|c|c|}
\hline p53 & $17 \mathrm{p} 13$ & Tumor suppressor & Mutation, hypermethilation & 30 \\
\hline$p 73$ & $1 \mathrm{p} 36$ & Apoptosis & Hypermethilation & $30,34,35,38$ \\
\hline PTEN & $10 \mathrm{q} 23$ & Tumor suppressor & Hypermethilation & $47-50$ \\
\hline RARB2 & $17 q 21$ & $\begin{array}{l}\text { Nuclear transcriptional } \\
\text { Regulator }\end{array}$ & Hypermethilation & $4,30,42,34,35,37$ \\
\hline RASSF-1 & $3 \mathrm{p} 21$ & Apoptosis & Hypermethilation & $4,32,51,37$ \\
\hline$R \boldsymbol{B}$ & $13 q 14$ & Tumor suppressor & Hypermethilation, mutation & 35 \\
\hline RUNX3 & $1 \mathrm{p} 36$ & Transcriptional regulator & Hypermethilation & 32,39 \\
\hline SFRP1 & $8 \mathrm{p} 11.21$ & Transcriptional regulator & Hypometilation & 52 \\
\hline SFRP1-2-4-5 & $\begin{array}{l}\text { 8p11.21 } \\
\text { 4q31.3 } \\
7 \mathrm{p} 14.1 \\
10 \mathrm{q} 24.1\end{array}$ & Transcriptional regulator & Hypermethilation & $52,38,53$ \\
\hline TCF21 & $6 q 23-q 24$ & $\begin{array}{l}\text { epithelial-mesenchymal } \\
\text { interactions }\end{array}$ & Hypermethilation & 38 \\
\hline THBS1 & $15 \mathrm{q} 15$ & $\begin{array}{l}\text { cell-to-cell and cell-to-matrix } \\
\text { interactions }\end{array}$ & Hypermethilation & 35 \\
\hline TIMP3 & $22 q 12$ & $\begin{array}{l}\text { epithelial-mesenchymal } \\
\text { interactions }\end{array}$ & Hypermethilation & 4,37 \\
\hline WIF1 & $12 \mathrm{q} 14$ & Transcriptional regulator & Hypermethilation & 32,52 \\
\hline$\sigma-14-3-3$ & $1 \mathrm{p} 36$ & Signal transduction & Hypermethilation & 30,34 \\
\hline
\end{tabular}

\subsection{CDKN2A}

The methylation rate of CDKN2A has been widely investigated and reported in the literature. CDKN2A gene maps on chromosome 9p21 and encodes the cell cycle regulatory protein p16, which inhibits the cyclin-dependent kinase 4 and 6 activity, inducing cell-cycle arrest in the G1 phase. The reported incidence of hypermethylation of p16 ranges from $23 \%$ to $76 \%$ in OSCC $[41,43,54-58]$. Some studies examined also this phenomenon in oral mucosa with different degree of dysplasia (pre-neoplastic lesions, OIN) [59,60] and in normal adjacent mucosa, showing higher values of hypermethylation in OIN compared to normal mucosa, but lower than in the OSCC.

\subsection{E-Cadherin and N-Cadherin}

CDH1 gene (cadherin 1 type 1) is located on chromosome 16q22.1 and encodes for E-cadherin, a 120-kd single-span transmembrane glycoprotein, with five extracellular and one cytoplasmic domain, interacting with catenins. This molecule is mainly involved in the formation of adhesive junctions in epithelial cells, playing a fundamental role in in many aspects of the establishment and maintenance of intercellular adhesion, cell polarity, intracellular signaling and tissue architecture. Several studies evaluating E-cadherin expression in different carcinomas, documented the crucial role of this molecule during tumor progression and invasion. In fact E-cadherin absence is strictly linked to alterations in cell key functions and motility. In addition it is shown that the loss of its expression is frequently involved in tissue metastasis. Similarly to others malignancies, it was shown a correlation between low expression of E-cadherin and a more aggressive behaviour of OSCC. Hypermethylation of CDH1 was 
also extensively reported [41,57,61-63]: in these studies the E-cadherin gene hypermethylation frequency ranged between $7 \%$ and $46 \%$ [30,64-65]. In a recent review, Vered et al. analyzed the recent literature evaluating the immunoexpression of E-cadherin in OSCC, highlighting the confusion existing about the expression of this protein in normal and neoplastic tissue. They stressed the need for a critical review of the IHC-based expression evaluation of this molecule, in order to better define the association between its expression and clinical outcome [66].

In a recent study, Di Domenico $\mathrm{M}$ examined $\mathrm{N}$-cadherin expression, a calcium-dependent adhesion protein, in series of 94 OSCC. Neoplastic tissue showed a significantly higher expression of this protein, almost exclusively cytoplasmic, than normal tissue. In addition tumors with high $\mathrm{N}$-cadherin value were characterized by a more aggressive behaviour. These data suggested that $\mathrm{N}$-cadherin could have a potential role in predicting the biological behavior of SCC [67].

\subsection{PTEN}

PTEN (phosphatase and tensin homolog deleted on chromosome 10) is a tumor-suppressor gene located on chromosome 10q23.3, the loss of which expression is thought to be involved in important cellular processes including survival, differentiation, proliferation, apoptosis and invasion. In addition, due to lack of control of the signaling pathways that mediate apoptosis and migration, such as Ras/phosphoinositide 3-kinase (PI3K)/AKT, it plays a fundamental role in tumor cell survival and proliferation and metastasis. PTEN is frequently deficient in several malignancies because of mutations or epigenetic changes [68,69] In addition evidences has also been provided supporting that $\mathrm{CpG}$ islands of the PTEN promoter are methylated in several type of human cancers, such as endometrial carcinoma [70], gastric [71], non-small-cell lung carcinoma [72] and cervical cancer [73]. Kurasawa et al. analyzed the immunohistochemical expression of PTEN in 113 OSCC and 9 OSCC cell-lines [47]. The resulting data showed a significant difference of expression between tumor samples and normal tissues. No mutations were showed, but in 4 out 6 OSCC cell lines a lower expression of PTEN mRNA were observed. Taken together these results supported the hypothesis that PTEN plays an important role in OSCC pathogenesis and that its down-regulation is due to hypermethylation [47]. However, the role of PTEN in OSCC remains uncertain. Squarize et al. demonstrated that aggressive OSCC did not express PTEN [48] and Shin et al. showed that the genetic or epigenetic inactivation of PTEN was related to OSCC carcinogenesis [49], while several authors didn't support this association [50,74,75]. Several studies have investigated the role of pTEN in OSCC and correlated the abnormal expression of PTEN to the occurrence, development and invasion of OSCC [76]. In a recent review, Diez-Perez et al. report the data relative to a comparison study between oral cancer tissue and normal mucosa, showing a $77.8 \%$ reduction of gene expression, due to its promoter methylation [42].

\section{4. $P 53$}

TP53 gene maps on chromosome 17p13.1 and encode a tumor suppressor protein, also called p53, involves in many fundamental cell processes, such as cell cycle progression, cellular differentiation, DNA-repair and apoptosis. When an endogenous or exogenous stress occurs, p53 levels increase and lead to block cell cycle, allowing the DNA-repair. Loss of p53 function alters the ability of cells to 
respond to stress or damage, leading to genomic instability. P53 is mutated in the majority of human cancers, including oral cancers, with frequency ranging from $25 \%$ to $69 \%$ [77-80]. In several instances, however, p53 shows a loss of function due to epigenetic events, instead of genetic alterations. This is the case of the epigenetic inactivation of p53 non mutated protein by the E6 protein of high-risk HPVs (mostly HPV16 and 18), in OSCC as in some laryngeal cancers (see below for further discussion about this topic).

\subsection{DAPK1}

DAPK1 (death associated protein kinase 1) gene maps on chromosome 9q34.1, it encodes a pro-apoptotic calcium/calmodulin regulated serine/threonine kinase inducing apoptosis (p53-dependent apoptotic checkpoint) $[43,58,81]$. The reported frequency of DAPK promoter hypermethylation ranges from $18 \%$ to $27 \%[64,82,83]$.

\section{6. $M G M T$}

MGMT gene is located on chromosome 10q26, it encodes MGMT (06-methylguanine-DNA methyl transferase), a DNA repair enzyme that removes adducts caused by alkylating agents; such DNA repair activity favors the resistance of cells to treatment-induced apoptosis. Silencing this gene allows alkylated guanine to accumulate, restoring apoptosis $[43,58]$. The frequency of hypermethylation in OSCC ranges from $7 \%$ to $68 \%[41,43,58,65,82-85]$.

\subsection{RARB2}

RARB2 (retinoic acid receptor B2 gene) is a tumor suppressor gene belonging to the RARB family, mapping on chromosome $3 \mathrm{p} 24$. It is frequently inactivated in cancer, mainly by methylation. It is linked with the deregulation of cell proliferation in tumors as well as in preneoplastic lesions. Promoter methylation of the RARB2 gene was generally reported in around $55 \%$ of lung SCLC, in $19 \%$ of urothelial carcinoma, in $27.5 \%$ of breast carcinomas, in prostate cancers, in endometrial carcinomas, colorectal carcinomas and it has been significantly associated with aggressive tumor phenotypes and patients survival in salivary glands carcinomas. RARB2 promoter methylation has been observed also in cancers of the head and neck region (67\%) and in a significant percentage of precancerous lesions of the same district $(>50 \%)$ [86]. Very interestingly, recent reports indicate that RARB2 methylation is independent from tumor site or stage, but is related to the higher age of patients (probably as an expression of the long time of action of carcinogens on the mucosal epithelium) and to the aggressiveness of tumors and poor prognosis of patients [45].

\subsection{RASSF1 and RASSF2}

RASSF1 (3p21.3) and RASSF2 (20p13) belong to the Ras association family (RASSF) of proteins involved in the Ras/PI3K/AKT pathways. Huang et al. showed that in almost the $50 \%$ of patients treated with radiotherapy Ras/PI3K/AKT pathways were activated in association with RASSF1A/RASSF2A gene silencing through promoter methylation [51]. In addition, Imai $\mathrm{T}$ et al. found RASSF2 methylated in $26 \%$ of OSCC evaluated [87]. 
Hypermethylation of p14ARK, p16 ${ }^{\mathrm{INK} 4 \mathrm{a}}, \mathrm{p} 15$, MGMT, DAPK, GSTP1, RARB and p53 have been found in dysplasia and in histologically normal appearing margin of OSCC resection. Several studies suggest that methylation could be considered as an early promising marker of malignant progression. However, other studies have failed to correlate the hypermethylated state with progression toward cancer of OINs or to recurrence of OSCC in the site of excision. Therefore, this aspect deserves further investigation on a greater series of cases $[12,43,58,59]$.

Less is known on the presence and role of hypomethylation: to date, it has been reported only the possible occurrence of SFRP1 (secreted frizzled-related protein 1) (8p11.21) hypometylation in OSCC, but the data are too few to achieve an overview of the phenomenon in these tumors. Contrary to Sogabe et al. who observed that SFRP1 together with SFRP2 and SFRP5 were methylated in OSCC, Pannone et al. found SFRP1 significantly demethylated in cancer $(p<0.05)$ [52].

\section{5. miRNA}

MicroRNAs (miRNAs) are a recently discovered class of non-coding endogenous small RNAs [88,89] which have a crucial role in the control of gene expression and are associated with promotion and progression of malignancies [90]. They are involved in many fundamental cellular processes such as proliferation, development, differentiation and apopotosis in normal and neoplastic cells, where they are referred to as oncomiRs (oncogenic miRNA). They act as mediators of epigenetic gene regulation, by interacting with mRNA, either by inhibiting mRNA translation or causing mRNA degradation [91]. Recent studies have been shown that miRNAs act as putative tumor suppressors and may also undergo epigenetic silencing in cancer [92,93]. Although there are still few studies focusing on the miRNA involvement in oral carcinogenesis, the interest about their functional roles in OSCC is rapidly growing. Cervigne et al. examined microRNA (miR) expression changes in 43 sequential progressive oral leukoplakia samples from 12 patients and 4 non-progressive leukoplakias from 4 different patients [94]. The findings were validated using quantitative RT-PCR in an independent cohort of 52 progressive dysplasias and oral squamous cell carcinomas (OSCCs), and 5 non-progressive dysplasias [94]. Global miR expression profiles distinguished progressive leukoplakia/OSCC from non-progressive leukoplakias/normal tissues. Of $109 \mathrm{miRs}$, which were highly expressed exclusively in progressive leukoplakia and invasive OSCC, miR21, miR181b, and miR345 expression was consistently increased and associated with increases in lesion severity during progression. The authors hypothesized that overexpression of miR21, miR181b, and miR345 may play an important role in malignant transformation [94]. Wong TS found that the level of miR-133a and miR-133B was significantly decreased in OSCC when compared with normal epithelia samples. These low levels led to the activation of a potential oncogene piruvate kinase type M2 [95]. Kozaki et al. investigated the miR-137 and miR-193a expression levels alteration in some OSCC cell lines, demonstrating that the epigenetic silencing of both miRNA, caused by DNA hypermethylation, could have a key function in oral cancer progression [46]. miR-17-92 was shown to play pleiotropic functions during both normal development and malignant transformation; it was demonstrated that the expression levels of mir-17-92 polycistronic cluster increased in cultured carcinoma cell lines in comparison to normal human keratinocytes [96,97]. Hu et al. demonstrated that miR-504 plays an important role during carcinogenesis, acting as a negative regulator of p53. In fact overexpression of miR-504 causes low 
demonstrated that miR-504 plays an important role during levels of the tumor suppressor [98]. The potential role of miR-504 as new diagnostic, prognostic and therapeutic tools has been recently discussed by $\mathrm{Wu}$ et al. and by Gorennchtein et al., both hypothesizing a clinic advantage in OSCC patient management $[99,100]$. Table 3 summarizes several miRNAs whose expression is deregulated in OSCC. The accumulating data about this topic let envisage mi-RNAs as one of the most valuable biomarkers and therapeutic targets in current OSCC research. During recent years, the trend of research in mi-RNA and OSCC field has evolved from solely searching altered specific miRNAs to exploring molecular networks and connections between miRNAs and signaling pathways involved in the progression of OSCC.

Table 3. Deregulated miRNA in squamous cell carcinoma of the oral region (OSCC).

\begin{tabular}{lll}
\hline Cellular function & \multicolumn{1}{c}{ microRNAs } & Expression in OSCC \\
\hline \multirow{2}{*}{$\begin{array}{l}\text { Proliferation and } \\
\text { apoptosis }\end{array}$} & miR-137, miR-193a, miR-133a, miR-133b, & Down-regulated \\
& miR-503, miR-15a & Up-regulated \\
MiR-21, miR-24 and miR-184 & Down-regulated \\
& miR-222 and miR-138 & Up-regulated \\
Chemoresistance & miR-211 and miR-31 & Down-regulated \\
& miR-21 & Up-regulated \\
\hline
\end{tabular}

\section{Chromatin Dynamics and Histones Modifications}

The chromatin structure is highly regulated by complex interactions between many molecular pathways, that influence normal and tumor cell fate, for that concerning DNA replication, transcription, and repair, cell growth and differentiation, apoptosis and every crucial cell functions. Histones and chromatin modifiers mainly induce changes of chromatin architecture. Histones have a structural role in the chromatin architecture entering into the constitution of nucleosomes. Acetylation, methylation, phosphorylation and ubiquitination are major histone modifications, combination of which may constitute the "histone code" that extends and modulates the genetic code [101,102]. Among molecules that regulate the chromatin assembly, histone chaperones play an essential role. They drive histones incorporation into newly synthesized or remodeled chromatin [103]. In this process, the Chromatin Assembly Factor-1 (CAF-1) exerts a pivotal role: it destabilizes heterochromatic structures during replication, allowing the replication machinery to progress through heterochromatin. CAF-1 is a protein complex, formed of three subunits with different molecular weight (p48, p60 and p150) and delivers histones H3 and H4 on newly synthesized DNA [104] during DNA replication and DNA repair. CAF-1 facilitates the incorporation and assembly into chromatin of H3K56 acetylated histones, in response to oxidative stress [105] and DNA damage [106-108]; moreover it contributes to resolve the mismatch-containing strands, restoring chromatin structure on the completion of double strand break repair [109]. In particular, the p48 subunit works as partner for the retinoblastoma protein RbAp48, participating in cell-growth suppression, and is involved in histone metabolism [110]; the p150 and p60 subunits are essential for the S-phase progression [111,112] and for the restoration of the original chromatin organization following DNA repair [113]. Moreover, p150 protein directly interacts with the proliferating cell nuclear antigen (PCNA) and is actively involved in proliferation-linked 
DNA repair processes [114]; the p60 subunit is highly required for the efficient progression through S-phase and, as expected, it is down-regulated in quiescent cells, and overexpressed in neoplastic cells [103]. CAF1/p60 has been found overexpressed in a series of human malignancies, including breast, prostate, melanoma, salivary glands, cervical, endometrial and renal cell cancers, in close association with their biological aggressiveness [111,115-119]. The role of CAF-1/p60 as new prognostic marker in oral tongue SCC has been also investigated. CAF1/p60 expression has been found significantly higher in OSCC with a worse prognosis, allowing the authors to propone this protein as a useful tool for evaluation of biological behavior of these tumors [118] [Figure 1].

Figure 1. A case of aggressive squamous cell carcinoma of tongue, Human Papillomavirus (HPV)-negative, showing a strong expression of chromatin Assembly Factor-1 $(\mathrm{CAF}-1) / \mathrm{p} 60$. The patient experienced two local recurrences, nodal and distant metastases and died for disease in a period between 1 and 3 years from diagnosis. In the higher magnification you can note most nuclei of tumor cells strongly immunostained for the protein $(1 \mathrm{~A}$ : original magnification $\times 200$; 1B: original magnification $\times 250$ ).

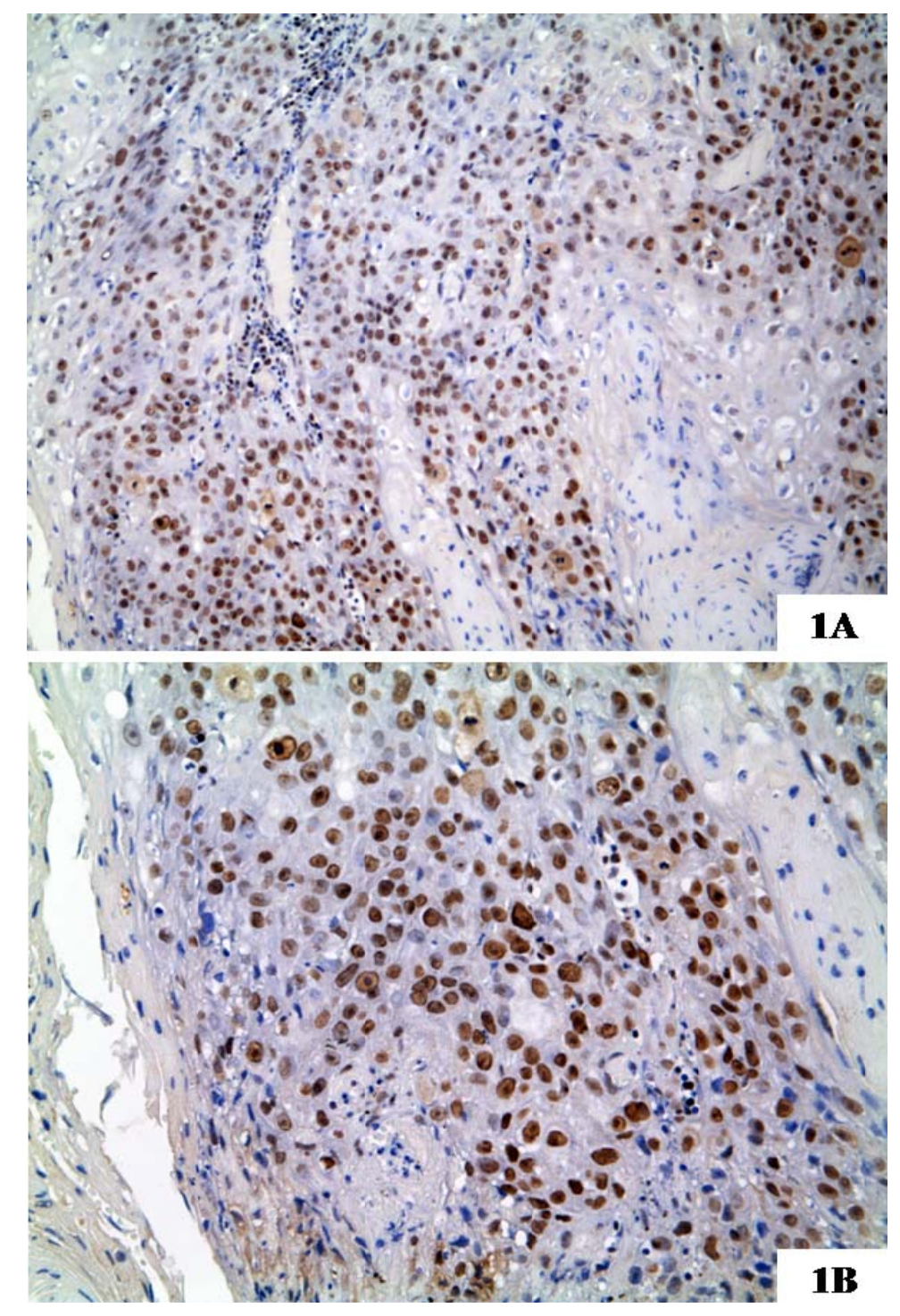


Several lines of evidence implicated histone acetylation in human malignancies. The histone acetylation status mainly depends on the activity of histone acetyltransferases (HATs) and histone deacetylases (HDACs). Some recent works evaluated the role of histone deacetylase (HDAC) inhibitors in OSCC cell lines and OSCC tissues [120-127]. HDAC inhibitors are a new group of anti-neoplastic drugs that promote acetylation of core histones, leading in turn to the uncoiling of chromatin and activation of several genes involved in the regulation mechanisms of cell survival, proliferation, differentiation, and apoptosis. Sakuma et al. found a higher expression of deacetylase 6 in OSCC cell lines and OSCC tissue samples in comparison to normal oral tissue and nine OSCC cell lines [120]. Moreover, Sato et al. highlighted the importance of timing of addition of HDAC inhibitors when used in combination with cisplatin, in a study performed on OSCC cell lines. In fact, CDDP-treated cells displayed varying degrees of apoptotic responses depending on timing of HDAC inhibitors addition [121]. Rihiishi et al. observed a cooperative effect between histone deacetylase (HDAC) inhibitor (suberoylanilide hydroxamic acid) on cisplatin (CDDP)-induced apoptosis on human OSCC cell lines [122]. Chang et al. evaluated the expression of Histone deacetylase 2 protein on 20 cases of oral epithelial dysplasia and 93 cases of OSCC [123]. In consideration of the resulting data showing that overexpression of the HDAC protein is a frequent event in OSCC, they suggested that Histone deacetylase 2 protein could be used as a prognostic factor in oral SCC. Based on reports supporting the useful association between HDAC inhibitors and some traditional chemotherapeutic agents, Shen and colleagues evaluated the potential combinative effect of low dose cisplatin andsuberoylanilide hydroxamic acid, in OSCC cell lines [125]. The authors concluded that concurrent treatment with SAHA enhanced tumor cell sensitivity to subtoxic doses of cisplatin.

\section{Human Papilloma Virus (HPV)}

High Risk Papillomavirus (HR-HPV) persistent infection has been recently indicated as an independent risk factor for head and neck cancers and, although it is still a "hot" debated topic, a growing body of literature has documented the link between high risk papillomavirus (HR-HPV) persistent infection of oral epithelium and the development of OSCC [7,8,128-132]. Miller and Johnstone, the first to publish a meta-analysis on HPV prevalence in precancer lesions, cancer and normal oral mucosa, showed that HPV was 2-3 times more likely to be detected in oral precancer lesions, and 4.7 times more likely to be present in oral carcinomas, when compared with normal mucosa [133]. Syrjänen reviewed the HPV literature published prior to 1998, and the pooled HPV detection rates in normal oral mucosa, OL and OSCC ranged from $13 \%$ to $33 \%$ depending on the technique used to detect HPV (PCR, ISH or both) [134].

In a recent meta-analysis study, Syrjänen et al. showed that HPV significantly increases the risk for OSCC, as compared with the controls (OR 3.98, 95\% CI: 2.62-6.02); nevertheless, in the total lack of prospective cohort studies, the authors were unable to take a position on the temporal relationship between HPV infection and oral malignancies [135]. The results of this meta-analysis showed a strong association between HPV and OSCC in accordance with previous studies [131-138].

The association between high risk papillomavirus (HR-HPV) persistent infection of oral epithelium and the development of OSCC characterizes a distinct subgroup of malignancy arisen in a younger and higher socio-economic group, often non-smokers/non-drinkers [139]. This subset of HR-HPV positive 
lesions shows different genetic and molecular profile and has been associated with a more favorable prognosis, compared to the HPV-negative ones, although more often they are poorly differentiated. In fact, HR-HPV-associated OSCCs are characterized by a significantly lower malignant progression rate and by a better responsiveness to chemo-and radiotherapy when compared with tumors of the same grade and stage, negative for viral infection [140,141]. However, it is not yet well known if the better biological behavior and the better response to the adjuvant therapies of the HR-HPV-associated OSCC might be due to the indirect action of innate or acquired cofactors, moreover to formally confirm the role of HPV as an etiological agent of OSCC, additional evidence is required.

From the molecular point of view, HR-HPV+ tumors are characterized by high genomic instability, due to a dysregulation of cell cycle control, epigenetically induced by the E6 and E7 HR-HPV oncoproteins [142]. E6 and E7 proteins bind and degrade, respectively, p53 and the retinoblastoma $(\mathrm{pRb})$ proteins, leading to the continuous expression of the cyclin-dependent kinases CDK4 and CDK6 [143], bypassing then the normal checkpoints. In particular, the degradation of $\mathrm{pRb}$ causes, through a positive feedback mechanism, the increase of intracellular protein p16INK4a and leads to deregulated tumor cell proliferation [144,145]. These alterations have a dramatical impact on the oral mucosa, driving its malignant transformation. Nevertheless, it is very intriguing to note that they involve the same genes commonly mutated in OSCC due to the classical risk factors (alcohol and tobacco use). Several host epigenetic changes have been ascribed to HPV virus. The HPV appears to increase the de novo methyltransferase, DNMT3b protein; although no HPV protein has been identified as the culprit for this increase in DNMT3b, a recent study has now shown that HPV E7-protein increases DNA methyltransferase enzymatic activity by directly interacting with DNMT1. E7 protein has also been described to bind HDACs and Nurd ATP-dependent remodeling complex. Moreover, E6 protein binds and inhibits p300/CBP HAT [146-149].

The existence of a different clinical course among OSCCs arisen in HR-HPV+ and HPV- patients, confirm the hypothesis that epimutations and genetic mutations may have different consequences on the biological behavior of tumors, even if they tend to occur in a combined manner in most of human malignancies.

\section{Considerations}

Unlike genetic alterations, epigenetic changes are potentially reversible, and this feature makes them attractive targets for therapeutic intervention. Recent progresses in the knowledge of epigenetics of cancer have allowed the development of several inhibitors of DNA methiltransferase (DNMT), such as 5-azacitidine and decitabine, and histone deacetylase, successfully used in the treatment of several malignancies of the hematopoietic system, lung and even HNC [150-153]. The US NIH repository for clinical trials reports some trials involving epigenetic-based drugs in head and neck cancer treatment: Azacitidine and Cisplatin have been tested in combined chemotherapy in advanced, recurrent and metastatic squamous cell carcinoma of head and neck but no data are available to date about the outcome of the study [154]. DNA methylation has been demonstrated to concur in the silencing of chemoresistance related genes; demethylating agents could improve the sensitivity of cancer cells to anticancer drugs [155]. The use of epigenetic inhibitors in association with traditional anticancer therapeutic agents looks very promising as a tool to improve the chemosensitivity of non-responsive 
cancers [156]. A peculiar clinical benefit in OSCC, might be expected, for example, from the synergistic effect of epigenetic silencing of RASSF1 and radiotherapy to minimize radioresistance in OSCC [51]. Unfortunately, to date most of these therapeutic agents have shown some drawbacks, being toxic in vitro and in vivo. Nevertheless, the chance to counteract epigenetically-driven alterations in cancer cells opens an exciting scenario for its possible future fall-out on OSCC patients' care.

\section{Acknowledgments}

We thank Amanda Tedeschi for the editing of the English style.

De Rosa and Staibano laboratories were supported by the Italian Ministry of Research (MIUR) funds; PRIN gov. numbers 2007YMS5NS_004, 20072JHN5W_002, 20089E83YR_002 and 2009ZY7L4X_004.

\section{References}

1. Parkin, D.M.; Bray, F.; Ferlay, J.; Pisani, P. Global cancer statistics, 2002. CA Cancer J. Clin. 2005, 55, 74-108.

2. Argiris, A.; Karamouzis, M.V.; Raben, D.; Ferris, R.L. Head and neck cancer. Lancet 2008, 371, 1695-1709.

3. Stewart, B.W.; Greim, H.; Shuker, D.; Kauppinen, T. Defence of IARC monographs. Lancet 2003, 361, doi:10.1016/S0140-6736(03)13003-6.

4. Mydlarz, W.K.; Hennessey, P.T.; Califano, J.A. Advances and perspectives in the molecular diagnosis of head and neck cancer. Expert Opin. Med. Diagn. 2010, 4, 53-65.

5. Jemal, A.; Siegel, R.; Ward, E.; Hao, Y.; Xu, J.; Murray, T.; Thun, M.J. Cancer statistics, 2008. CA Cancer J. Clin. 2008, 58, 71-96.

6. Blot, W.J.; McLaughlin, J.K.; Winn, D.M.; Austin, D.F.; Greenberg, R.S.; Preston-Martin, S.; Bernstein, L.; Schoenberg, J.B.; Stemhagen, A.; Fraumeni, J.F., Jr. Smoking and drinking in relation to oral and pharyngeal cancer. Cancer Res. 1988, 48, 3282-3287.

7. Gillison, M.L.; Koch, W.M.; Capone, R.B.; Spafford, M.; Westra, W.H.; Wu, L.; Zahurak, M.L.; Daniel, R.W.; Viglione, M.; Symer, D.E.; Shah, K.V.; Sidransky, D. Evidence for a causal association between human papillomavirus and a subset of head and neck cancers. J. Natl. Cancer Inst. 2000, 92, 709-720.

8. Gillison, M.L.; D’Souza, G.; Westra, W.; Sugar, E.; Xiao, W.; Begum, S.; Viscidi, R. Distinct risk factor profiles for human papillomavirus type 16-positive and human papillomavirus type 16-negative head and neck cancers. J. Natl. Cancer Inst. 2008, 100, 407-420.

9. Schlecht, N.F. Prognostic value of human papillomavirus in the survival of head and neck cancer patients: An overview of the evidence. Oncol. Rep. 2005, 14, 1239-1247.

10. Chaturvedi, A.K.; Engels, E.A.; Anderson, W.F.; Gillison, M.L. Incidence trends for human papillomavirus-related and -unrelated oral squamous cell carcinomas in the United States. J. Clin. Oncol. 2008, 26, 612-619.

11. Fakhry, C.; Westra, W.H.; Li, S.; Cmelak, A.; Ridge, J.A.; Pinto, H.; Forastiere, A.; Gillison, M.L. Improved survival of patients with human papillomavirus-positive head and neck squamous cell carcinoma in a prospective clinical trial. J. Natl. Cancer Inst. 2008, 100, 261-269. 
12. Lingen, M.W.; Pinto, A.; Mendes, R.A.; Franchini, R.; Czerninski, R.; Tilakaratne, W.M.; Partridge, M.; Peterson, D.E.; Woo, S.B. Genetics/epigenetics of oral premalignancy: Current status and future research. Oral Dis. 2011, 17, 7-22.

13. Saintigny, P.; Zhang, L.; Fan, Y.-H.; El-Naggar, A.K.; Papadimitrakopoulou, V.A.; Feng, L.; Lee, J.J.; Kim, E.S.; Hong, W.K.; Mao, L. Gene expression profiling predicts the development of oral cancer. Cancer Prev. Res. 2011, 4, 218-229.

14. Kyrgidis, A.; Tzellos, T.G.; Triaridis, S. Melanoma: Stem cells, sun exposure and hallmarks for carcinogenesis, molecular concepts and future clinical implications. J. Carcinog. 2010, 9, doi: 10.4103/1477-3163.62141.

15. Santos-Rosa, H.; Caldas, C. Chromatin modifier enzymes, the histone code and cancer. Eur. J. Cancer 2005, 41, 2381-2402.

16. Rountree, M.R.; Bachman, K.E.; Herman, J.G.; Baylin, S.B. DNA methylation, chromatin inheritance, and cancer. Oncogene 2001, 20, 3156-3165.

17. Egger, G.; Liang, G.; Aparicio, A.; Jones, P.A. Epigenetics in human disease and prospects for epigenetic therapy. Nature 2004, 429, 457-463.

18. Feinberg, A.P.; Ohlsson, R.; Henikoff, S. The epigenetic progenitor origin of human cancer. Nat. Rev. 2006, 7, 21-33.

19. Feinberg, A.P.; Tycko, B. The history of cancer epigenetics. Nat. Rev. Cancer 2004, 4, 143-153.

20. Jones, P.A.; Baylin, S.B. The fundamental role of epigenetic events in cancer. Nat. Rev. Genet. 2002, 3, 415-428.

21. Board, R.E.; Knight, L.; Greystoke, A.; Blackhall, F.H.; Hughes, A.; Dive, C.; Ranson, M. DNA methylation in circulating tumour DNA as a biomarker for cancer. Biomark. Insights 2008, 2 , 307-319.

22. Bird, A. DNA methylation patterns and epigenetic memory. Genes Dev. 2002, 16, 6-21.

23. Eden, A.; Gaudet, F.; Waghmare, A.; Jaenisch, R. Chromosomal instability and tumors promoted by DNA hypomethylation. Science. 2003, 300, doi:10.1126/science.1083557.

24. Bonazzi, V.F.; Irwin, D.; Hayward, N.K. Identification of candidate tumor suppressor genes inactivated by promoter methylation in melanoma. Genes Chromosom. Cancer 2009, 48, 10-21.

25. Feinberg, A.P.; Cui, H.; Ohlsson, R. DNA methylation and genomic imprinting: Insights from cancer into epigenetic mechanisms. Semin. Cancer Biol. 2002, 12, 389-398.

26. Robertson, K.D. DNA methylation and human disease. Nat. Rev. Genet. 2005, 6, 597-610.

27. Martinez, R.; Martin-Subero, J.I.; Rohde, V.; Kirsch, M.; Alaminos, M.; Fernandez, A.F.; Ropero, S.; Schackert, G.; Esteller, M. A microarray-based DNA methylation study of glioblastoma multiforme. Epigenetics 2009, 4, 255-264.

28. Herman, J.G. Hypermethylation of tumor suppressor genes in cancer. Semin. Cancer Biol. 1999, 9, 359-367.

29. Baylin, S.B. DNA methylation and gene silencing in cancer. Nat. Clin. Pract. Oncol. 2005, 2, S4-S11.

30. Shaw, R. The epigenetics of oral cancer. Int. J. Oral. Maxillofac. Surg. 2006, 35, 101-108.

31. Shaw, R.J.; Hall, G.L.; Woolgar, J.A.; Lowe, D.; Rogers, S.N.; Field, J.K.; Liloglou, T.; Risk, J.M. Quantitative methylation analysis of resection margins and lymph nodes in oral squamous cell carcinoma. Br. J. Oral. Maxillofac. Surg. 2007, 45, 617-622. 
32. Supić, G.; Kozomara, R.; Branković-Magić, M.; Jović, N.; Magić, Z. Gene hypermethylation in tumor tissue of advanced oral squamous cell carcinoma patients. Oral Oncol. 2009, 45, 1051-1057.

33. Supic, G.; Jovic, N.; Kozomara, R.; Zeljic, K.; Magic, Z. Interaction between the MTHFR C677T polymorphism and alcohol - Impact on oral cancer risk and multiple DNA methylation of tumor-related genes. J. Dent. Res. 2011, 90, 65-70.

34. Radhakrishnan, R.; Kabekkodu, S.; Satyamoorthy, K. DNA hypermethylation as an epigenetic mark for oral cancer diagnosis. J. Oral Pathol. Med. 2011, 40, 665-679.

35. Fan, C.Y. Epigenetic alterations in head and neck cancer: Prevalence, clinical significance, and implications. Curr. Oncol. Rep. 2004, 6, 152-161.

36. Shaw, R.J.; Hall, G.L.; Lowe, D.; Liloglou, T.; Field, J.K.; Sloan, P.; Risk, J.M. The role of pyrosequencing in head and neck cancer epigenetics: correlation of quantitative methylation data with gene expression. Arch. Otolaryngol. Head Neck Surg. 2008, 134, 251-256.

37. Glazer, C.A.; Chang, S.S.; Ha, P.K.; Califano, J.A. Applying the molecular biology and epigenetics of head and neck cancer in everyday clinical practice. Oral Oncol. 2009, 45, 440-446.

38. Bennett, K.L.; Hackanson, B.; Smith, L.T.; Morrison, C.D.; Lang, J.C.; Schuller, D.E.; Weber, F.; Eng, C.; Plass, C. Tumor suppressor activity of CCAAT/enhancer binding protein alpha is epigenetically down-regulated in head and neck squamous cell carcinoma. Cancer Res. 2007, 67, 4657-4664.

39. de Freitas Cordeiro-Silva, M.; Oliveira, Z.F.; de Podestá, J.R.; Gouvea, S.A.; von Zeidler, S.V.; Louro, I.D. Methylation analysis of cancer-related genes in non-neoplastic cells from patients with oral squamous cell carcinoma. Mol. Biol. Rep. 2011, 38, 5435-5441.

40. Calmon, M.F.; Rodrigues, R.V.; Kaneto, C.M.; Moura, R.P.; Silva, S.D.; Mota, L.D.; Pinheiro, D.G.; Torres, C.; de Carvalho, A.F.; Cury, P.M.; et al. Epigenetic silencing of CRABP2 and MX1 in head and neck tumors. Neoplasia 2009, 11, 1329-1339.

41. Viswanathan, M.; Tsuchida, N.; Shanmugam, G. Promoter hypermethylation profile oftumorassociated genes p16, p15, hMLH1, MGMT and E-cadherin in oral squamous cell carcinoma. Int. J. Cancer 2003, 105, 41-46.

42. Díez-Pérez, R.; Campo-Trapero, J.; Cano-Sánchez, J.; López-Durán, M.; Gonzalez-Moles, M.A.; Bascones-Ilundain, J.; Bascones-Martinez, A. Methylation in oral cancer and pre-cancerous lesions (Review). Oncol. Rep. 2011, 25, 1203-1209.

43. Kulkarni, V.; Saranath, D. Concurrent hypermethylation of multiple regulatory genes in chewing tobacco associated oral squamous cell carcinomas and adjacent normal tissues. Oral. Oncol. 2004, 40, 145-153.

44. Mancuso, M.; Matassa, D.S.; Conte, M.; Colella, G.; Rana, G.; Fucci, L.; Piscopo, M. H3K4 histone methylation in oral squamous cell carcinoma. Acta Biochim. Pol. 2009, 56, 405-410.

45. Lee, E.S.; Issa, J.P.; Roberts, D.B.; Williams, M.D.; Weber, R.S.; Kies, M.S.; El-Naggar, A.K. Quantitative promoter hypermethylation analysis of cancer-related genes in salivary gland carcinomas: Comparison with methylation-specific PCR technique and clinical significance. Clin. Cancer Res. 2008, 14, 2664-2672.

46. Kozaki, K.; Imoto, I.; Mogi, S.; Omura, K.; Inazawa, J. Exploration of tumor-suppressive microRNAs silenced by DNA hypermethylation in oral cancer. Cancer Res. 2008, 68, 2094-2105. 
47. Kurasawa, Y.; Shiiba, M.; Nakamura, M.; Fushimi, K.; Ishigami, T.; Bukawa, H.; Yokoe, H.; Uzawa, K.; Tanzawa, H. PTEN expression and methylation status in oral squamous cell carcinoma. Oncol. Rep. 2008, 19, 1429-1434.

48. Squarize, C.H.; Castilho, R.M.; Santos Pinto, D., Jr. Immunohistochemical evidence of PTEN in oral squamous cell carcinoma and its correlation with the histological malignancy grading system. J. Oral Pathol. Med. 2002, 31, 379-384.

49. Shin, K.H., Kim, J.M.; Rho, K.S.; Park, K.H., Oh, J.E.; Min, B.M. Inactivation of the PTEN gene by mutation, exonic deletion, and loss of transcript in human oral squamous cell carcinomas. Int. J. Oncol. 2002, 21, 997-1001.

50. Lee, J.I.; Soria, J.C.; Hassan, K.A.; El-Naggar, A.K.; Tang, X.; Liu, D.D.; Hong, W.K.; Mao, L. Loss of PTEN expression as a prognostic marker for tongue cancer. Arch. Otolaryngol. Head Neck Surg. 2001, 127, 1441-1445.

51. Huang, K.H.; Huang, S.F.; Chen, I.H.; Liao, C.T.; Wang, M.; Hsieh, L.L. Methylation of RASSF1A, RASSF2A, and HIN-1 is associated with poor outcome after radiotherapy, but not surgery, in oral squamous cell carcinoma. Clin. Cancer Res. 2009, 15, 4174-4180

52. Pannone, G.; Bufo, P.; Santoro, A.; Franco, R.; Aquino, G.; Longo, F.; Botti, G.; Serpico, R.; Cafarelli, B.; Abbruzzese, A.; et al. WNT pathway in oral cancer: Epigenetic inactivation of WNT-inhibitors. Oncol. Rep. 2010, 24, 1035-1041.

53. Sogabe, Y.; Suzuki, H.; Toyota, M.; Ogi, K.; Imai, T.; Nojima, M.; Sasaki, Y.; Hiratsuka, H.; Tokino, T. Epigenetic inactivation of SFRP genes in oral squamous cell carcinoma. Int. J. Oncol. 2008, 32, 1253-1261.

54. Huang, M.J.; Yeh, K.T.; Shih, H.C.; Wang, Y.F.; Lin, T.H.; Chang, J.Y.; Shih, M.C.; Chang, J.G. The correlation between $\mathrm{CpG}$ methylation and protein expression of P16 in oral squamous cell carcinomas. Int. J. Mol. Med. 2002, 10, 551-554.

55. Nakahara, Y.; Shintani, S.; Mihara, M.; Ueyama, Y.; Matsumura, T. High frequency of homozygous deletion and methylation of p16(INK4A) gene in oral squamous cell carcinomas. Cancer Lett. 2001, 163, 221-228.

56. Ogi, K.; Toyota, M.; Ohe-Toyota, M.; Tanaka, N.; Noguchi, M.; Sonoda, T.; Kohama, G.; Tokino, T. Aberrant methylation of multiple genes and clinicopathological features in oral squamous cell carcinoma. Clin. Cancer Res. 2002, 8, 3164-3171.

57. Maruya, S.; Issa, J.P.; Weber, R.S.; Rosenthal, D.I.; Haviland, J.C.; Lotan, R.; El-Naggar, A.K. Differential methylation status of tumor-associated genes in head and neck squamous carcinoma: Incidence and potential implications. Clin. Cancer Res. 2004, 10, 3825-3830.

58. Kato, K.; Hara, A.; Kuno, T.; Mori, H.; Yamashita, T., Toida, M.; Shibata, T. Aberrant promoter hypermethylation of p16 and MGMT genes in oral squamous cell carcinomas and the surrounding normal mucosa. J. Cancer Res. Clin. Oncol. 2006, 132, 735-743.

59. Kresty, L.A.; Mallery, S.R.; Knobloch, T.J.; Song, H.; Lloyd, M.; Casto, B.C.; Weghorst, C.M. Alterations of p16(INK4a) and p14(ARF) in patients with severe oral epithelial dysplasia. Cancer Res. 2002, 62, 5295-5300. 
60. Takeshima, M.; Saitoh, M.; Kusano, K.; Nagayasu, H.; Kurashige, Y.; Malsantha, M.; Arakawa, T.; Takuma, T.; Chiba, I.; Kaku, T.; et al. High frequency of hypermethylation of p14, p15 and p16 in oral pre-cancerous lesions associated with betel-quid chewing in Sri Lanka. J. Oral Pathol. Med. 2008, 37, 475-479.

61. Saito, Y.; Takazawa, H.; Uzawa, K.; Tanzawa, H.; Sato, K. Reduced expression of E-cadherin in oral squamous cell carcinoma: Relationship with DNA methylation of 5' CpG island. Int. J. Oncol. 1998, 12, 293-298.

62. Nakayama, S.; Sasaki, A.; Mese, H.; Alcalde, R.E.; Tsuji, T.; Matsumura, T. The E-cadherin gene is silenced by $\mathrm{CpG}$ methylation in human oral squamous cell carcinomas. Int. J. Cancer 2001, 93, $667-673$.

63. Chang, H.W.; Chow, V.; Lam, K.Y.; Wei, W.I.; Yuen, A. Loss of E-cadherin expression resulting from promoter hypermethylation in oral tongue carcinoma and its prognostic significance. Cancer 2002, 94, 386-392.

64. Hasegawa, M.; Nelson, H.H.; Peters, E.; Ringstrom, E.; Posner, M.; Kelsey, K.T. Patterns of gene promoter methylation in squamous cell cancer of the head and neck. Oncogene. 2002, 21, 4231-4236.

65. Viet, C.T.; Jordan, R.C.; Schmidt, B.L. DNA promoter hypermethylation in saliva for the early diagnosis of oral cancer. J. Calif. Dent. Assoc. 2007, 35, 844-849.

66. Vered, M.; Allon, I.; Buchner, A.; Dayan, D. E-cadherin in oral SCC: An analysis of the confusing literature and new insights related to its immunohistochemical expression. Histol. Histopathol. 2012, 27, 141-150.

67. Di Domenico, M.; Pierantoni, G.M.; Feola, A.; Esposito, F.; Laino, L.; de Rosa, A.; Rullo, R.; Mazzotta, M.; Martano, M.; Sanguedolce, F.; et al. Prognostic significance of N-cadherin expression in oral squamous cell carcinoma. Anticancer Res. 2011, 12, 4211-4218.

68. Renner, O.; Blanco-Aparicio, C.; Carnero, A. Genetic modelling of the PTEN/AKT pathway in cancer research. Clin. Transl. Oncol. 2008, 10, 618-627.

69. Zhu, Y.; Wloch, A.; Wu, Q.; Peters, C.; Pagenstecher, A.; Bertalanffy, H.; Sure, U. Involvement of PTEN promoter methylation in cerebral cavernous malformations. Stroke 2009, 40, 820-826.

70. Salvesen, H.B.; MacDonald, N.; Ryan, A.; Jacobs, I.J.; Lynch, E.D.; Akslen, L.A.; Das, S. PTEN methylation is associated with advanced stage and microsatellite instability in endometrial carcinoma. Int. J. Cancer 2001, 91, 22-26.

71. Kang, Y.H.; Lee, H.S.; Kim, W.H. Promoter methylation and silencing of PTEN in gastric carcinoma. Lab. Invest. 2002, 82, 285-291.

72. Soria, J.C.; Lee, H.Y.; Lee, J.I.; Wang, L.; Issa, J.P.; Kemp, B.L.; Liu, D.D.; Kurie, J.M.; Mao, L.; Khuri, F.R. Lack of PTEN expression in non-small cell lung cancer could be related to promoter methylation. Clin. Cancer Res. 2002, 8, 1178-1184.

73. Yang, H.J.; Liu, V.W.; Wang, Y.; Tsang, P.C.; Ngan, H.Y. Differential DNA methylation profiles in gynecological cancers and correlation with clinico-pathological data. BMC Cancer 2006, 6, doi:10.1186/1471-2407-6-212.

74. Chen, Q.; Samaranayake, L.P.; Zhou, H.; Xiao, L. Homozygous deletion of the PTEN tumor-suppressor gene is not a feature in oral squamous cell carcinoma. Oral Oncol. 2000, 36, 95-99. 
75. Mavros, A.; Hahn, M.; Wieland, I.; Koy, S.; Koufaki, O.N.; Strelocke, K.; Koch, R.; Haroske, G.; Schackert, H.K.; Eckelt, U. Infrequent genetic alterations of the tumor suppressor gene PTEN/MMAC1 in squamous cell carcinoma of the oral cavity. J. Oral Pathol. Med. 2002, 31, 270-276.

76. Koch, R.; Haroske, G.; Schackert, H.K.; Eckelt, U. Infrequent genetic alterations of the tumor suppressor gene PTEN/MMAC1 in squamous cell carcinoma of the oral cavity. J. Oral Pathol. Med. 2002, 31, 270-276.

77. Levine, A.J.; Momand, J.; Finlay, C.A. The p53 tumour suppressor gene. Nature 1991, 351, 453-456.

78. Boyle, J.O.; Hakim, J.; Koch, W., van der Riet, P.; Hruban, R.H.; Roa, R.A.; Correo, R.; Eby, Y.J.; Ruppert, J.M.; Sidransky, D. The incidence of p53 mutations increases with progression of head and neck cancer. Cancer Res. 1993, 53, 4477-4480.

79. Caamano, J.; Zhang, S.Y.; Rosvold, E.A.; Bauer, B.; Klein-Szanto, A.J. p53 alterations in human squamous cell carcinomas and carcinoma cell lines. Am. J. Pathol. 1993, 142, 1131-1139.

80. Baral, R.; Patnaik, S.; Das B.R. Co-overexpression of p53 and c-myc proteins linked with advanced stages of betel- and tobacco-related oral squamous cell carcinomas from eastern India. Eur. J. Oral Sci. 1998, 106, 907-913.

81. Ha, P.K.; Califano, J.A. Promoter methylation and inactivation of tumour-suppressor genes in oral squamous-cell carcinoma. Lancet Oncol. 2006, 7, 77-82.

82. Sanchez-Cespedes, M.; Esteller, M.; Wu, L.; Nawroz-Danish, H.; Yoo, G.H.; Koch, W.M.; Jen, J.; Herman, J.G.; Sidransky, D. Gene promoter hypermethylation in tumors and serum of head and neck cancer patients. Cancer Res. 2000, 60, 892-895.

83. Rosas, S.L.; Koch, W.; da Costa Carvalho, M.G.; Wu, L.; Califano, J.; Westra, W.; Jen, J.; Sidransky, D. Promoter hypermethylation patterns of p16, O6-methylguanine-DNAmethyltransferase, and death-associated protein kinase in tumors and saliva of head and neck cancer patients. Cancer Res. 2001, 61, 939-942.

84. Roth, M.J.; Abnet, C.C.; Hu, N.; Wang, Q.H.; Wie, W.Q.; Green, L.; D’Alelio, M.; Qiao, Y.L.; Dawsey, S.M.; Taylor, P.R.; Woodson, K. p16, MGMT, RARbeta2, CLDN3, CRBP and MT1G gene methylation in esophageal squamous cell carcinoma and its precursor lesions. Oncol. Rep. 2006, 15, 1591-1597.

85. Sawhney, M.; Rohatgi, N.; Kaur, J.; Gupta, S.D.; Deo, S.V.; Shukla, N.K.; Ralhan, R. MGMT expression in oral precancerous and cancerous lesions: Correlation with progression, nodal metastasis and poor prognosis. Oral Oncol. 2007, 43, 515-522.

86. Youssef, E.M.; Lotan, D.; Issa, J.; Wakasa, K.; Fan, Y.H.; Mao, L.; Hassan, K.; Feng, L.; Lee, J.J.; Lippman, S.M.; et al. Hypermethylation of the retinoic acid receptor- $\beta(2)$ gene in head and neck carcinogenesis. Clin. Cancer Res. 2004, 10, 1733-1742.

87. Imai, T.; Toyota, M.; Suzuki, H.; Akino, K.; Ogi, K.; Sogabe, Y.; Kashima, L.; Maruyama, R.; Nojima, M.; Mita, H.; et al. Epigenetic inactivation of RASSF2 in oral squamous cell carcinoma. Cancer Sci. 2008, 99, 958-966. 
88. Sigalotti, L.; Covre, A.; Fratta, E.; Parisi, G.; Colizzi, F.; Rizzo, A.; Danielli, R.; Nicolay, H.J.; Coral, S.; Maio, M. Epigenetics of human cutaneous melanoma: Setting the 66 research on Melanoma: A glimpse into current directions and future trends stage for new therapeutic strategies. J. Transl. Med. 2010, 8, 56.

89. Guil, S.; Esteller, M. DNA methylomes, histone codes and miRNAs: Tying it all together. Int. J. Biochem. Cell Biol. 2009, 41, 87-95.

90. Calin, G.A.; Croce, C.M. MicroRNA signatures in human cancers. Nat. Rev. Cancer 2006, 6, 857-866.

91. Sood, P.; Krek, A.; Zavolan, M.; Macino, G.; Rajewsky, N. Cell-type-specific signatures of microRNAs on target mRNA expression. Proc. Natl. Acad. Sci. USA 2006, 103, 2746-2751.

92. Lujambio, A.; Ropero, S.; Ballestar, E.; Fraga, M.F.; Cerrato, C.; Setién, F.; Casado, S.; Suarez-Gauthier, A.; Sanchez-Cespedes, M.; Git. A.; et al. Genetic unmasking of an epigenetically silenced microRNA in human cancer cells. Cancer Res. 2007, 67, 1424-1429.

93. Saito, Y.; Liang, G.; Egger, G.; Friedman, J.M.; Chuang, J.C.; Coetzee, G.A.; Jones, P.A. Specific activation of microRNA-127 with downregulation of the proto-oncogene BCL6 by chromatin-modifying drugs in human cancer cells. Cancer Cell 2006, 9, 435-443.

94. Cervigne, N.K.; Reis, P.P.; Machado, J.; Sadikovic, B.; Bradley, G.; Galloni, N.N.; Pintilie, M.; Jurisica, I.; Perez-Ordonez, B.; Gilbert, R.; et al. Identification of a microRNA signature associated with progression of leukoplakia to oral carcinoma. Hum. Mol. Genet. 2009, 18, 4818-4829.

95. Wong, T.S.; Liu, X.B.; Chung-Wai Ho, A.; Po-Wing Yuen, A.; Wai-Man Ng, R.; Ignace Wei, W. Identification of pyruvate kinase type M2 as potential oncoprotein in squamous cell carcinoma of tongue through microRNA profiling. Int. J. Cancer 2008, 123, 251-257.

96. Olive, V.; Jiang, I., He, L. mir-17-92, a cluster of miRNAs in the midst of the cancer network. Int. J. Biochem. Cell Biol. 2010, 42, 1348-1354.

97. Jevnaker, A.M.; Khuu, C.; Kjøle, E.; Bryne, M.; Osmundsen, H. Expression of members of the miRNA17-92 cluster during development and in carcinogenesis. J. Cell. Physiol. 2011, 226, 2257-2266.

98. Hu, W.; Chan, C.S.; Wu, R.; Zhang, C.; Sun, Y.; Song, J.S.; Tang, L.H.; Levine, A.J.; Feng, Z. Negative regulation of tumor suppressor p53 by microRNA miR-504. Mol. Cell 2010, 38, 689-699.

99. Wu, B.H.; Xiong, X.P.; Jia, J.; Zhang, W.F. MicroRNAs: New actors in the oral cancer scene. Oral Oncol. 2011, 47, 314-319.

100. Gorenchtein, M.; Poh, C.F.; Saini, R.; Garnis, C. MicroRNAs in an oral cancer context—From basic biology to clinical utility. J. Dent. Res. 2011, doi:10.1177/0022034511431261.

101. Jenuwein, T.; Allis, C.D. Translating the histone code. Science 2001, 293, 1074-1080.

102. Strahl, B.D.; Allis, C.D. The language of covalent histone modifications. Nature 2000, 403, 41-45.

103. Ramirez-Parra, E.; Gutierrez, C. The many faces of chromatin assembly factor 1. Trends Plant Sci. 2007, 12, 570-576.

104. Ridgway, P.; Almouzni, G. CAF-1 and the inheritance of chromatin states: At the crossroads of DNA replication and repair. J. Cell Sci. 2000, 113, 2647-2658. 
105. Das, C.; Lucia, M.S.; Hansen, K.C.; Tyler, J.K. CBP/p300-mediated acetylation of histone H3 on lysine 56. Nature 2009, 459, 113-117.

106. Li, Q.; Huang, Y.; Xiao, N.; Murray, V.; Chen, J.; Wang, J. Real time investigation of protein folding, structure, and dynamics in living cells. Methods Cell Biol. 2008, 90, 287-325.

107. Chen, C.C.; Tyler, J. Chromatin reassembly signals the end of DNA repair. Cell Cycle 2008, 7, 3792-3797.

108. Kadyrova, L.Y.; Blanko, E.R.; Kadyrov, F.A. CAF-I-dependent control of degradation of the discontinuous strands during mismatch repair. Proc. Natl. Acad. Sci. USA 2011, 108, 2753-2758.

109. Kim, J.A.; Haber, J.E. Chromatin assembly factors Asf1 and CAF-1 have overlapping roles in deactivating the DNA damage checkpoint when DNA repair is complete. Proc. Natl. Acad. Sci. USA 2009, 106, 1151-1156.

110. Henikoff, S. Versatile assembler. Nature 2003, 423, 814- 817.

111. Polo, S.E.; Theocharis, S.E.; Klijanienko, J.; Savignoni, A.; Asselain, B.; Vielh, P.; Almouzni, G. Chromatin Assembly Factor-1, a marker of clinical value to distinguish quiescent from proliferating cells. Cancer Res. 2004, 64, 2371-2381.

112. Ye, X.; Franco, A.A.; Santos, H.; Nelson, D.M.; Kaufmann, P.D.; Adams, P.D. Defective S phase chromatin assembly causes DNA damage, activation of the $\mathrm{S}$ phase checkpoint, and $\mathrm{S}$ phase arrest. Mol. Cell 2003, 11, 341-351.

113. Gaillard, P.H.; Martini, E.M.; Kaufman, P.D.; Stillman, B.; Moustacchi, E.; Almouzni, G. Chromatin assembly coupled to DNA repair: A new role for chromatin assembly factor I. Cell 1996, 86, 887-896.

114. Techenio, T.; Casella, J.F.; Heidmann, T. A truncated form of human CAF-1 p150 subunits impairs the maintenance of transcriptional gene silencing in mammalian cells. Mol. Cell. Biol. 2001, 21, 953-961.

115. Staibano, S.; Mascolo, M.; Mancini, F.P.; Kisslinger, A.; Salvatore, G.; Di Benedetto, M.; Chieffi, P.; Altieri, V.; Prezioso, D.; Ilardi, G.; et al. Overexpression of chromatin assembly factor-1 (CAF-1) p60 is predictive of adverse behaviour of prostatic cancer. Histopathology 2009 , 54, 580-589.

116. Mascolo, M.; Vecchione, M.L.; Ilardi, G.; Scalvenzi, M.; Molea, G.; Di Benedetto, M.; Nugnes, L.; Siano, M.; de Rosa, G.; Staibano, S. Overexpression of Chromatin Assembly Factor-1/p60 helps to predict the prognosis of melanoma patients. BMC Cancer 2010, 24, doi: 10.1186/1471-2407-10-63.

117. Staibano, S.; Mascolo, M.; Rocco, A.; Lo Muzio, L.; Ilardi, G.; Siano, M.; Pannone, G.; Vecchione, M.L.; Nugnes, L.; Califano, L.; et al. The proliferation marker Chromatin Assembly Factor-1 is of clinical value in predicting the biological behaviour of salivary gland tumours. Oncol. Rep. 2011, 25, 13-22.

118. Staibano, S.; Mignogna, C.; Lo Muzio, L.; Mascolo, M.; Salvatore, G.; Di Benedetto, M.; Califano, L.; Rubini, C.; de Rosa, G. Chromatin assembly factor-1 (CAF-1)-mediated regulation of cell proliferation and DNA repair: A link with the biological behaviour of squamous cell carcinoma of the tongue? Histopathology 2007, 50, 911-919.

119. Polo, S.E.; Theocharis, S.E.; Grandin, L.; Gambotti, L.; Antoni, G.; Savignoni, A.; Asselain, B.; Patsouris, E.; Almouzni, G. Clinical significance and prognostic value of chromatin assembly factor-1 overexpression in human solid tumours. Histopathology 2010, 57, 716-724. 
120. Sakuma, T.; Uzawa, K.; Onda, T.; Shiiba, M.; Yokoe, H.; Shibahara, T.; Tanzawa, H. Aberrant expression of histone deacetylase 6 in oral squamous cell carcinoma. Int. J. Oncol. 2006, 29, 117-124.

121. Sato, T.; Suzuki, M.; Sato, Y.; Echigo, S.; Rikiishi, H. Sequence-dependent interaction between cisplatin and histone deacetylase inhibitors in human oral squamous cell carcinoma cells. Int. J. Oncol. 2006, 28, 1233-1241.

122. Rikiishi, H.; Shinohara, F.; Sato, T.; Sato, Y.; Suzuki, M.; Echigo, S. Chemosensitization of oral squamous cell carcinoma cells to cisplatin by histone deacetylase inhibitor, suberoylanilide hydroxamic acid. Int. J. Oncol. 2007, 30, 1181-1188.

123. Chang, H.H.; Chiang, C.P.; Hung, H.C.; Lin, C.Y.; Deng, Y.T.; Kuo, M.Y. Histone deacetylase 2 expression predicts poorer prognosis in oral cancer patients. Oral Oncol. 2009, 45, 610-614.

124. Chung, Y.L.; Lee, M.Y.; Pui, N.N. Epigenetic therapy using the histone deacetylase inhibitor for increasing therapeutic gain in oral cancer: Prevention of radiationinduced oral mucositis and inhibition of chemical-induced oral carcinogenesis. Carcinogenesis 2009, 30, 1387-1397.

125. Shen, J.; Huang, C.; Jiang, L.; Gao, F.; Wang, Z.; Zhang, Y.; Bay, J.; Zhou, H.; Chen, Q. Enhancement of cisplatin induced apoptosis by suberoylanilide hydroxamic acid in human oral squamous cell carcinoma cell lines. Biochem. Pharmacol. 2007, 73, 1901-1909.

126. Murakami, J.; Asaumi, J.; Maki, Y.; Tsujigiwa, H.; Kuroda, M.; Nagai, N.; Yanagi, Y.; Inoue, T.; Kawasaki, S.; Tanaka, N.; et al. Effects of demethylating agent 5-aza-2(0)-deoxycytidine and histone deacetylase inhibitor FR901228 on maspin gene expression in oral cancer cell lines. Oral Oncol. 2004, 40, 597-603.

127. Murakami, J.; Asaumi, J.; Kawai, N.; Tsujigiwa, H.; Yanagi, Y.; Nagatsuka, H.; Inoue, T.; Kokeguchi, S.; Kawasaki, S.; Kuroda, M.; et al. Effects of histone deacetylase inhibitor FR901228 on the expression level of telomerase reverse transcriptase in oral cancer. Cancer Chemother. Pharmacol. 2005, 56, 22-28.

128. D’Souza, G.; Kreimer, A.R.; Viscidi, R.; Pawlita, M.; Fakhry, C.; Koch, W.M.; Westra, W.H.; Gillison, M.L. Case-control study of human papillomavirus and oropharyngeal cancer. N. Engl. J. Med. 2007, 356, 1944-1956.

129. Adelstein, D.J.; Rodriguez, C.P. Human papillomavirus: Changing paradigms in oropharyngeal cancer. Curr. Oncol. Rep. 2010, 12, 115-120.

130. Stock, M.L.; Peterson, L.M.; Houlihan, A.E.; Walsh, L.A. Influence of oral sex and oral cancer information on young adults' oral sexual-risk cognitions and likelihood of hpv vaccination. J. Sex Res. 2012, doi: 10.1111/j.1365-263X.2011.01219.x.

131. Murugan, A.K.; Munirajan, A.K.; Tsuchida, N. Ras oncogenes in oral cancer: The past 20 years. Oral Oncol. 2012, doi: 10.1016/j.oraloncology.2011.12.006.

132. Sanders, A.; Slade, G.; Patton, L. National prevalence of oral HPV infection and related risk factors in the US adult population. Oral Dis. 2011, doi: 10.1111/j.1601-0825.2011.01892.x.

133. Miller, C.S.; Johnstone, B.M. Human papillomavirus as a risk factor for oral squamous cell carcinoma: A meta- analysis, 1982-1997. Oral Surg. Oral Med. Oral. Pathol. Oral Radiol. Endod. 2001, 91, 622-635. 
134. Syrjanen, S.; Syrjanen, K. HPV Infections of the Oral Mucosa. In Papillomavirus Infections in Human Pathology; Syrjanen, K., Syrjanen, S., Eds.; John Wiley \& Sons: New York, NY, USA, 2000; Chapter 17, pp. 379-412.

135. Syrjänen, S.; Lodi, G.; von Bültzingslöwen, I.; Aliko, A.; Arduino, P.; Campisi, G.; Challacombe, S.; Ficarra, G.; Flaitz, C.; Zhou, H.M.; et al. Human papillomaviruses in oral carcinoma and oral potentially malignant disorders: A systematic review. Oral Dis. 2011, 17, 58-72.

136. Termine, N.; Panzarella, V.; Falaschini, S.; Russo, A., Matranga, D.; Lo Muzio, L.; Campisi, G. HPV in oral squamous cell carcinoma vs. head and neck squamous cell carcinoma biopsies: A meta-analysis (1988-2007). Ann. Oncol. 2008, 10, 1681-1690.

137. Kreimer, A.R.; Clifford, G.M.; Boyle, P.; Franceschi, S. Human papillomavirus types in head and neck squamous cell carcinomas worldwide: A systematic review. Cancer Epidemiol. Biomark. Prev. 2005, 14, 467-475.

138. Smith, E.M.; Ritchie, J.M.; Yankowitz, J.; Swarnavel, S.; Wang, D.; Haugen, T.H.; Turek, L.P. Human papillomavirus prevalence and types in newborns and parents: Concordance and modes of transmission. Sex Transm. Dis. 2004, 1, 57-62.

139. Dayyani, F.; Etzel, C.J.; Liu, M.; Ho, C.H.; Lippman, S.M.; Tsao, A.S. Meta-analysis of the impact of human papillomavirus (HPV) on cancer risk and overall survival in head and neck squamous cell carcinomas (HNSCC). Head Neck Oncol. 2010, 2, doi:10.1186/1758-3284-2-15.

140. Zhao, D.; Xu, Q.G.; Chen, X.M.; Fan, M.W. Human papillomavirus as an independent predictor in oral squamous cell cancer. Int. J. Oral Sci. 2009, 1, 119-125.

141. Shi, W.; Kato, H.; Perez-Ordonez, B.; Pintilie, M.; Huang, S.; Hui, A.; O’Sullivan, B.; Waldron, J.; Cummings, B.; Kim, J.; et al. Comparative prognostic value of HPV16 E6 mRNA compared with in situ hybridization for human oropharyngeal squamous carcinoma. J. Clin. Oncol. 2009, 27, 6213-6221.

142. Wiest, T.; Schwarz, E.; Enders, C.; Flechtenmacher, C.; Bosch, F.X. Involvement of intact HPV16 E6/E7 gene expression in head and neck cancers with unaltered p53 status and perturbed pRb cell cycle control. Oncogene 2002, 21, 1510-1517.

143. Boyer, S.N.; Wazer, D.E.; Band, V. E7 protein of human papilloma virus-16 induces degradation of retinoblastoma protein through the ubiquitin-proteasome pathway. Cancer Res. 1996, 56, 4620-4624.

144. Snow, A.; Laudadio, J. Human papillomavirus detection in head and neck squamous cell carcinomas. Adv. Anat. Pathol. 2010, 17, 394-403.

145. Smeets, S.J.; Hesselink, A.T.; Speel, E.J.; Haesevoets, A.; Snijders, P.J.; Pawlita, M.; Meijer, C.J.; Braakhuis, B.J.; Leemans, C.R.; Brakenhoff, R.H. A novel algorithm for reliable detection of human papillomavirus in paraffin embedded head and neck cancer specimen. Int. J. Cancer 2007, 121, 2465-2472.

146. Patel, D.; Huang, S.M.; Baglia, L.A.; McCance, D.J. The E6 protein of human papillomavirus type 16 binds to and inhibits co-activation by CBP and p300. EMBO J. 1999, 18, 5061-5072.

147. Longworth, M.S.; Laimins, L.A. The binding of histone deacetylases and the integrity of zinc finger-like motifs of the E7 protein are essential for the life cycle of human papillomavirus type 31. J. Virol. 2004, 78, 3533-3541. 
148. Lin, T.S.; Lee, H.; Chen, R.A.; Ho, M.L.; Lin, C.Y.; Chen, Y.H.; Tsai, Y.Y.; Chou, M.C.; Cheng, Y.W. An association of DNMT3b protein expression with P16INK4a promoter hypermethylation in non-smoking female lung cancer with human papillomavirus infection. Cancer Lett. 2005, 226, 77-84

149. Burgers, W.A.; Blanchon, L.; Pradhan, S.; de Launoit, Y.; Kouzarides, T.; Fuks, F. Viral oncoproteins target the DNA methyltransferases. Oncogene 2007, 26, 1650-1655.

150. Gore, D.S. Combination therapy with DNA methyltransferase inhibitors in hematologic malignancies. Nat. Clin. Pract. Oncol. 2005, 2, S30-S35.

151. Quintás-Cardama, A.; Santos, F.P.; Garcia-Manero, G. Histone deacetylase inhibitors for the treatment of myelodysplastic syndrome and acute myeloid leukemia. Leukemia. 2011, 25, 226-235.

152. Momparler, R.L.; Ayoub, J. Potential of 5-aza-2'-deoxycytidine (Decitabine) a potent inhibitor of DNA methylation for therapy of advanced non-small cell lung cancer. Lung Cancer 2001, 34, S111-S115.

153. Coombes, M.M.; Briggs, K.L.; Bone, J.R.; Clayman, G.L.; El-Naggar, A.K.; Dent, S.Y. Resetting the histone code at CDKN2A in HNSCC by inhibition of DNA methylation. Oncogene 2003, 22 , 8902-8911.

154. ClinicalTrials Home Page. Available online: http://www.clinicaltrials.gov (accessed on 21 February 2012).

155. Balch, C.; Yan, P.; Craft, T.; Young, S.; Skalnik, D.G.; Huang, T.H.; Nephew, K.P. Antimitogenic and chemosensitizing effects of the methylation inhibitor zebularine in ovarian cancer. Mol. Cancer Ther. 2005, 4, 1505-1514.

156. Suzuki, M.; Shinohara, F.; Nishimura, K.; Echigo, S.; Rikiishi, H. Epigenetic regulation of chemosensitivity to 5-fluorouracil and cisplatin by zebularine in oral squamous cell carcinoma. Int. J. Oncol. 2007, 31, 1449-1456.

(C) 2012 by the authors; licensee MDPI, Basel, Switzerland. This article is an open access article distributed under the terms and conditions of the Creative Commons Attribution license (http://creativecommons.org/licenses/by/3.0/). 